\title{
Impact of Watershed Development on Soil Characteristics in Kuthanagere Micro-Watershed in Ramanagar District of Karnataka, India
}

\author{
J.S. Arun Kumar", H.S. Shivaramu and S.N. Anilkumar \\ AICRP on Potential crops, University of Agricultural Sciences, GKVK, \\ Bangalore-560065, Karnataka, India \\ *Corresponding author
}

\section{A B S T R A C T}

\begin{tabular}{|l|}
\hline Ke y w o r d s \\
$\begin{array}{l}\text { Watershed, Length } \\
\text { of growing period } \\
\text { (LGP), Plant } \\
\text { available water } \\
\text { holding capacity } \\
\text { (PAWC). }\end{array}$ \\
\hline Article Info \\
\hline $\begin{array}{l}\text { Accepted: } \\
\text { 23 September } 2017 \\
\text { Available Online: } \\
\text { 10 October } 2017\end{array}$
\end{tabular}

\section{Keywords}

Watershed, Length (LGP), Plant ailable water (PAWC).
Kuthanagere micro watershed is located in Ramanagar district. It was developed in 1995 with bench mark information on GIS and monitored for 19 years for changes in soil- site characteristics. The normal annual rainfall of the Kuthanagere watershed was $1027.6 \mathrm{~mm}$ in 45 rainy days. The area under 3 to 5 per cent slope was considerably reduced (by $6 \%$ ) as against increase in area (by $13 \%$ ) under 1 to 3 per cent slope class. Further the area under moderate erosion was decreased by 4.66 per cent and that became qualified under none to slight erosion class. An increase in overall soil depth of the watershed area by $15.30 \mathrm{~cm}$ was observed in 17 years, besides increase in PAWC by $9.98 \mathrm{~mm}$ and an overall LGP of 5 days. The area (27\% of the watershed) under very shallow soil $(7.5$ to $22.5 \mathrm{~cm}$ depth class) was transformed and became qualified under shallow soils $(22.5$ to $45 \mathrm{~cm}$ depth class). With respect to the change in texture of the soil, sand per cent was decreased by 5.25 per cent as against the increase in silt per cent by 1.76 per cent and clay by 3.61 per cent. Thus the area under sandy loam was decreased by 5.83 per cent and sandy clay loam was in turn increased by 15.4 per cent indicating transformation of watershed area from coarse texture to fine texture soils.

\section{Introduction}

In the recent past, concept of watershed based holistic development has emerged as one of the potential approaches in rainfed areas, which can lead to higher productivity and sustainability in agricultural production. The period of soil moisture availability vis-à-vis length of growing period (LGP) is broadly a function of effective rainfall among the climatic parameters, slope and ground water table among site parameters and depth, available water holding capacity and texture among the soil parameters. LGP of land or soil, determine the type of crops and cropping system besides the type of vegetation in that area. For better soil moisture management in dry lands, watershed is being considered as a management unit to efficiently conserve and use the water through harvesting, recycling and its retention in the soil profile besides raising ground water table. Therefore, a long term impact of watershed development (19 years from 1995 to 2014) on the above parameters vis- $a$ - vis moisture availability was studied for Kuthanagere micro watershed, near Bangalore in Karnataka having an area of 250 ha $\left(13^{0} 06^{\prime} \mathrm{N}\right.$ latitude and $77^{\circ} 11^{\prime}$ E longitude at an altitude of 869 $\mathrm{m}$ above mean sea level). 


\section{Materials and Methods}

The selected watershed lies $60 \mathrm{~km}$ away from Bangalore in Magadi taluk of Ramanagar district. The normal annual rainfall of the Kuthanagere watershed was $1027.6 \mathrm{~mm}$ in 45 rainy days. The major portion of it is received during April to November with peak during September $(201.9 \mathrm{~mm})$. The detailed soil survey of Kuthanagere watershed was carried out using cadastral map of 1:5000 as base map. The survey was carried out before (1995) and after 19 years (2014) of watershed development using the standard soil survey procedures as described in the Soil Survey Manual (IARI, 1971). At first instance, traversing of the study area was done to have an inventory of physiography, stream lines, geology, vegetation and land use. Based on the bench mark study report, master profiles were identified and locations were fixed to study pedons. Thirteen pedons were studied in the field for their morphological features. Soil samples from identified horizons of each pedon were collected for analysis of physicochemical properties.

The difference in the moisture holding capacity at 33 and $1500 \mathrm{kPa}$ was multiplied by bulk density and soil depth to calculate the plant available water holding capacity (PAWC) of each soil series (Shivaramu and Niranjana, 2010). Length of Growing Period (LGP) was calculated based on FAO model of water balance analysis which involves plotting of rainfall and potential evapotranspiration values over time at monthly interval (Higgins and Kassam, 1981). Soil map and other thematic maps of the watershed were prepared using GIS, besides Soil suitability map for different rain fed crops based on the suitability criteria. Thirteen soil series (Kuthanagere-1 to Kuthanagere- 13) were identified (Shivaramu, 2012) during the benchmark survey in 1995 and all of them were studied for the above soil- site characteristics. Most of these belong to Alfisols with Ustic and isohyperthermic moisture and temperature regimes, respectively.

\section{Results and Discussion}

The change in soil characteristics, land use and land cover was studied after 19 years of watershed development based on the bench mark data. The area under 3 to 5 per cent slope was considerably reduced (by $6 \%$ ) as against increase in area (by $13 \%$ ) under 1 to 3 per cent slope class. However, no remarkable changes in area under other slope classes like hill slopes were noticed. The area under moderate erosion was decreased from 45.04 to 37.24 per cent and it became qualified under none to slight erosion class (increase by $7.8 \%$ ). Although the area under severe erosion on hill slopes before the watershed development was slightly reduced (32.49 to $29.40 \%$ ) after 19 years, however not as conspicuous as in other erosion classes.

The data on changes in soil depth due to watershed development is presented in table 2. Watershed development, not only undertaken extensive bunding but also undertaken land leveling in some area under study particularly owned by well-off farmers who were ready to invest in the land development for raising commercial crops/ plantations. Kuthanagere- 2 and Kuthanagere3 soil series, shown a reduction in soil depth due to watershed development either due leveling, their occurrences on ridge areas of the watershed or both. In a span of 19 years of watershed development, the overall soil depth of the watershed area was increased by 15.30 $\mathrm{cm}$ (from $75.39 \mathrm{~cm}$ to $113 \mathrm{~cm}$ ). Around 27\% of the watershed area majority belonged to Kuthanagere- 13 soil series was having a soil depth of $13 \mathrm{~cm}$ as Ap horizon (Table 1) coming under a very shallow soil depth class of 7.5 to $22.5 \mathrm{~cm}$. After a gap of 19 years, the 
same soil series shown to develop another subsurface horizon characterized as $\mathrm{Bw}$ horizon having a depth of $12-30 \mathrm{~cm}$ in addition to the above existing Ap horizon (Table 1). Thus, Kuthanagere-13 having 27 per cent of the watershed area transformed and became qualified under shallow soil class (22.5 to $45 \mathrm{~cm}$ depth class) due to the watershed development elapsed 19 years, resulting in no area to be classified under very shallow soil depth class. Further, overall increase by $9.98 \mathrm{~mm}$ in plant available water holding capacity (PAWC) of the soils of the watershed was also observed (from $61.85 \mathrm{~mm}$ to $71.82 \mathrm{~mm}$ ). Thus, due to increase in soil depth and PAWC, LGP of the watershed was raised from 210 days to 215 days. Although the LGP is mainly a climate dependant parameter, particularly the rainfall distribution, it also was increased due increase in PAWC of the entire soil profile depth averaged across the watershed (Table 2).

Yadav et al., (1995) observed that Vertisols of $200 \mathrm{~cm}$ soil depth could hold and retain 200$250 \mathrm{~mm}$ of soil moisture as against $130-150$ mm only by Alfisols of same $200 \mathrm{~cm}$ depth. With respect to the change in texture of the soil (Table 3), sand per cent was decreased by 5.25 per cent as against the increase in silt per cent by 1.76 per cent and clay by 3.61 per cent.

The area under, gravelly sandy loam, loamy sand and sandy loam was decreased by 6.70 per cent and the area under sandy clay loam alone was in turn increased by 13.94 per cent indicating transformation of watershed area from coarse texture to fine texture soils. The study on organic carbon percentage showed an increase from 0.49 per cent in 1995 to 0.59 per cent in 2014 indicating the built up of overall fertility levels of the soils of Kuthanagere watershed due to watershed development vis $-a-v i$ improved land use and land cover due to the afforestation in non- arable lands and agro-forestry systems in arable lands. Due to the creation of rain water harvesting structures in the watershed (12 farm ponds, 4 nala bunds and 2 check dams) having an area of 250 ha, an increase in rain water storage capacity of the watershed was observed to the extent of $25000 \mathrm{~m}^{3}$ (25 TCM). This water is being used by the farmers for life saving protective irrigation, vegetable cultivation, fish culture and pot irrigation to newly planted perennial orchard plants, besides contributing maintained ground water table, if not raised. Watershed shows a conspicuous change in land use and land cover from annual crops to perennial mango based agri - horti systems during 19 years elapse of the watershed development. Before and after implementation of structures and suitable land use systems, the study at an interval of 10 years (1993, 2003 and 2013) of watershed development showed conspicuous change in land use and land cover. Before implementation of watershed, the land was shown to be severely eroded losing almost Ap horizon and part of $\mathrm{B}$ horizon with sparse or no vegetation cover. Therefore alternate land use plan was developed and established based on the suitability of different soil sites and land forms in the watershed. Accordingly the systems developed were as follows.

Agri-horticulture system with widely spaced (30 to 40 trees per ha.) Mango (Mangifera indica) intermixed with one or two other economical trees like curry leaves (Murraya koenigii). Cinnamon (Cinnamon zelanicum), Pomogranate (Punica granatus), Jack fruit (Artocarpus integrafolia), Tamarind (Tamarindus indica) and tree like Castor

Silvi-pasture on scarp slopes of hill lock, foot hills, and severely eroded gully lands and on field bunds. Contour V trenches of $0.25 \mathrm{~m} / \mathrm{sq}$. Cross section dug at 5 meter interval were planted with different trees species at high density of 2000 plants per ha considering the 
low survival rate of less than 50 per cent. The spaces between trenches were established with fodder legumes of Styloxanthus species. The tree species were Acacia auriculiformis, Cassia siamia, Dalbergia sisso, Azadirichata indica, pongamia glabra, Lecana leucosecephala, Ficus spp, Albezia lebbeck, bamboo and etc. along with fruits like Phylanthus niroori, Annona scamosa, Emblica officinalis, Sizygium cumins etc.

Table.1 Comparison of horizon and soil depth after 19 years of watershed development with Benchmark Survey (1995) of Kuthanagere watershed

\begin{tabular}{|c|c|c|c|c|c|}
\hline \multirow{2}{*}{$\begin{array}{l}\text { SI. } \\
\text { No. } \\
\end{array}$} & \multirow{2}{*}{ Soil series } & \multicolumn{2}{|c|}{1995} & \multicolumn{2}{|c|}{2014} \\
\hline & & Horizon & Depth (cm) & Horizon & Depth (cm) \\
\hline \multirow[t]{5}{*}{1.} & Kuthanagere -1 & Ap & $0-15$ & Ap & $0-12$ \\
\hline & & $\mathrm{Bt}_{1}$ & $15-43$ & $\mathrm{Bt}_{1}$ & $12-46$ \\
\hline & & $\mathrm{Bt}_{2}$ & $43-74$ & $\mathrm{Bt}_{2}$ & $46-78$ \\
\hline & & $\mathrm{Bt}_{3}$ & $74-106$ & $\mathrm{Bt}_{3}$ & $78-125$ \\
\hline & & $\mathrm{C}$ & $106-110^{+}$ & & \\
\hline \multirow[t]{6}{*}{2.} & Kuthanagere -2 & Ap & $0-12$ & Ap & $0-12$ \\
\hline & & $\mathrm{Bt}_{1}$ & $12-40$ & $\mathrm{Bt}_{1}$ & $12-46$ \\
\hline & & $\mathrm{Bt}_{2}$ & $40-60$ & $\mathrm{Bt}_{2}$ & $46-71$ \\
\hline & & $\mathrm{Bt}_{3}$ & $60-113$ & $\mathrm{Bt}_{3}$ & $71-98$ \\
\hline & & $\mathrm{BC}$ & $113-155$ & $\mathrm{Bt}_{4}$ & $98-122$ \\
\hline & & $\mathrm{C}$ & $155^{+}$ & $\mathrm{Bc}$ & $122-138$ \\
\hline \multirow[t]{6}{*}{3.} & Kuthanagere -3 & $\mathrm{Ap}$ & $0-12$ & Ap & $0-14$ \\
\hline & & $\mathrm{Bt}_{1}$ & $12-31$ & $\mathrm{Bt}_{1}$ & 14-49 \\
\hline & & $\mathrm{Bt}_{2}$ & $31-72$ & $\mathrm{Bt}_{2}$ & $49-88$ \\
\hline & & $\mathrm{Bt}_{3}$ & $72-105$ & $\mathrm{Bc}$ & $88-125$ \\
\hline & & $\mathrm{Bt}_{4}$ & $105-125$ & & \\
\hline & & $\mathrm{BC}$ & $125-140^{+}$ & & \\
\hline \multirow[t]{6}{*}{4.} & Kuthanagere -4 & Ap & $0-10$ & Ap & $0-11$ \\
\hline & & $\mathrm{B}$ & $10-30$ & $\mathrm{Bt}_{1}$ & $11-31$ \\
\hline & & $\mathrm{B}$ & $30-50$ & $\mathrm{Bt}_{2}$ & $31-54$ \\
\hline & & $\mathrm{BC}$ & $50-65$ & $\mathrm{Bt}_{3}$ & $54-76$ \\
\hline & & $\mathrm{R}$ & $65^{+}$ & $\mathrm{Bt}_{4}$ & 76-104 \\
\hline & & & & $\mathrm{Bt}_{5}$ & 104-133 \\
\hline \multirow[t]{3}{*}{5.} & Kuthanagere -5 & $\mathrm{A}$ & $0-10$ & $\mathrm{~A}$ & $0-14$ \\
\hline & & $\mathrm{Bw}$ & $10-28$ & $\mathrm{Bt}_{1}$ & $14-33$ \\
\hline & & $\mathrm{Cr}$ & $28-51$ & $\mathrm{Bt}_{2}$ & $33-51$ \\
\hline \multirow[t]{3}{*}{6.} & Kuthanagere -6 & Ap & $0-12$ & $\mathrm{AP}$ & $0-22$ \\
\hline & & $\mathrm{Bt}_{1}$ & $12-34$ & $\mathrm{Bt}_{1}$ & $22-55$ \\
\hline & & $\mathrm{Bt}_{2}$ & $34-60$ & $\mathrm{Bt}_{2}$ & $55-89$ \\
\hline
\end{tabular}




\begin{tabular}{|c|c|c|c|c|c|}
\hline & & $\mathrm{BC}$ & $60-79$ & $\mathrm{Bc}$ & $89-118$ \\
\hline & & $\mathrm{C}$ & $79-110^{+}$ & & \\
\hline \multirow[t]{5}{*}{7.} & Kuthanagere -7 & Ap & $0-10$ & Ap & $0-17$ \\
\hline & & B & $10-26$ & $\mathrm{Bt}_{1}$ & $17-45$ \\
\hline & & $\mathrm{B}$ & $26-46$ & $\mathrm{Bt}_{2}$ & $45-80$ \\
\hline & & $\mathrm{B}$ & $46-90$ & $\mathrm{Cb}$ & $80-112$ \\
\hline & & $\mathrm{C}$ & $90-100^{+}$ & & \\
\hline \multirow[t]{6}{*}{8.} & Kuthanagere -8 & Ap & $0-43$ & Ap & $0-18$ \\
\hline & & $\mathrm{AC} 1$ & $14-38$ & $\mathrm{Bw}_{1}$ & $18-34$ \\
\hline & & $\mathrm{AC} 2$ & $38-56$ & $\mathrm{Bw}_{2}$ & $34-62$ \\
\hline & & $\mathrm{AC} 3$ & $56-80$ & $\mathrm{Bw}_{3}$ & $62-102$ \\
\hline & & $\mathrm{AC} 4$ & $80-93$ & $\mathrm{Bw}_{4}$ & $102-115$ \\
\hline & & $\mathrm{C}$ & $93-120$ & & \\
\hline \multirow[t]{6}{*}{9.} & Kuthanagere -9 & Ap & $0-9$ & Ap & $0-11$ \\
\hline & & B & $9-18$ & $\mathrm{Bt}_{1}$ & $11-45$ \\
\hline & & B & $18-84$ & $\mathrm{Bt}_{2}$ & $45-81$ \\
\hline & & B & $84-129$ & $\mathrm{Bt}_{3}$ & $81-108$ \\
\hline & & $\mathrm{BC}$ & $129-150^{+}$ & $\mathrm{Bt}_{4}$ & $108-128$ \\
\hline & & & & $\mathrm{Bt}_{5}$ & $128-151$ \\
\hline \multirow[t]{5}{*}{10.} & Kuthanagere -10 & Ap & $0-10$ & Ap & $0-10$ \\
\hline & & $\mathrm{Bt}_{1}$ & $10-38$ & $\mathrm{Bt}_{1}$ & $10-34$ \\
\hline & & $\mathrm{Bt}_{2}$ & $38-68$ & $\mathrm{Bt}_{2}$ & $34-56$ \\
\hline & & $\mathrm{BC}$ & $68-102$ & $\mathrm{Bt}_{3}$ & $56-90$ \\
\hline & & $\mathrm{C}$ & $102-130$ & $\mathrm{Bc}$ & $90-120$ \\
\hline \multirow[t]{6}{*}{11.} & Kuthanagere -11 & Ap & $0-13$ & Ap & $0-16$ \\
\hline & & $\mathrm{Bw}$ & $13-32$ & $\mathrm{Bt}_{1}$ & $16-42$ \\
\hline & & $\mathrm{Bw}_{2}$ & $32-56$ & $\mathrm{Bt}_{2}$ & $42-71$ \\
\hline & & $\mathrm{Bw}_{3}$ & $56-76$ & $\mathrm{Bt}_{3}$ & $71-115$ \\
\hline & & $\mathrm{Bw}_{4}$ & $76-92$ & $\mathrm{Bt}_{4}$ & $115-129$ \\
\hline & & $\mathrm{Bw}_{5}$ & $92-150^{+}$ & $\mathrm{Bt}_{5}$ & $129-150$ \\
\hline \multirow[t]{5}{*}{12.} & Kuthanagere -12 & Ap & $0-16$ & $\mathrm{Ap}$ & $0-18$ \\
\hline & & A13 & $16-35$ & $\mathrm{Bw}_{1}$ & $18-41$ \\
\hline & & $\mathrm{Bw}$ & $35-50$ & $\mathrm{Bw}_{2}$ & $41-65$ \\
\hline & & $\mathrm{BC}$ & $50-77$ & $\mathrm{Bw}_{3}$ & $65-88$ \\
\hline & & $\mathrm{C}$ & $77^{+}$ & $\mathrm{Cb}$ & 88-101 \\
\hline \multirow[t]{2}{*}{13.} & Kuthanagere -13 & Ap & $0-13$ & Ap & $0-12$ \\
\hline & & $\mathrm{C}$ & $13-43^{+}$ & $\mathrm{Bw}$ & $12-30$ \\
\hline
\end{tabular}


Table.2 Changes in depth, PAWC and LGP with Benchmark Survey of Kuthanagere watershed after gap of 17 years of its development

\begin{tabular}{|c|c|c|c|c|c|c|c|c|c|}
\hline \multirow{2}{*}{ Soil series } & \multicolumn{3}{|c|}{ Depth (cm) } & \multicolumn{3}{|c|}{ PAWC (mm) } & \multicolumn{3}{|c|}{ LGP (days) } \\
\hline & 1995 & 2014 & change & 1995 & 2014 & change & 1995 & 2014 & change \\
\hline Kuthanagere -1 & 106 & 125 & 19 & 41.1 & 48.47 & 7.37 & 206 & 210 & 4.00 \\
\hline Kuthanagere -2 & 155 & 138 & -17 & 118.3 & 105.33 & -12.97 & 224 & 221 & -3.00 \\
\hline Kuthanagere -3 & 140 & 125 & -15 & 108.6 & 96.96 & -11.64 & 221 & 220 & -1.00 \\
\hline Kuthanagere -4 & 65 & 133 & 68 & 40.4 & 82.66 & 42.26 & 206 & 218 & 12.00 \\
\hline Kuthanagere -5 & 51 & 51 & 0 & 18.9 & 34.43 & 15.53 & 199 & 206 & 7.00 \\
\hline Kuthanagere -6 & 79 & 118 & 39 & 31.5 & 47.05 & 15.55 & 202 & 209 & 7.00 \\
\hline Kuthanagere -7 & 90 & 112 & 22 & 43.9 & 54.63 & 10.73 & 207 & 213 & 6.00 \\
\hline Kuthanagere -8 & 93 & 115 & 22 & 40.2 & 49.71 & 9.51 & 204 & 209 & 5.00 \\
\hline Kuthanagere -9 & 150 & 151 & 1 & 111.7 & 112.44 & 0.74 & 223 & 223 & 0.00 \\
\hline Kuthanagere -10 & 102 & 120 & 18 & 108.2 & 127.29 & 19.09 & 221 & 230 & 9.00 \\
\hline Kuthanagere -11 & 150 & 150 & 0 & 68.5 & 68.50 & 0 & 213 & 213 & 0.00 \\
\hline Kuthanagere -12 & 77 & 101 & 24 & 61.8 & 81.06 & 19.26 & 211 & 218 & 7.00 \\
\hline Kuthanagere -13 & 13 & 30 & 17 & 10.9 & 25.15 & 14.25 & 195 & 202 & 7.00 \\
\hline $\begin{array}{c}\text { Weighted } \\
\text { Average }\end{array}$ & 75.39 & $\begin{array}{c}81.85 \\
(76.69) *\end{array}$ & $6.46(1.30)^{*}$ & 61.85 & 71.82 & 9.98 & 210 & 215 & 5.00 \\
\hline
\end{tabular}


Table.3 Long term impact (17 years elapse) of watershed development on changes in sand, silt, clay (\%) and organic carbon (\%) in Ap horizon in kuthanagere watershed

\begin{tabular}{|c|c|c|c|c|c|c|c|c|c|c|c|c|}
\hline \multirow{2}{*}{ Soil Series } & \multicolumn{3}{|c|}{ Sand $(\%)$} & \multicolumn{3}{|c|}{ Silt (\%) } & \multicolumn{3}{|c|}{ Clay (\%) } & \multicolumn{3}{|c|}{ Organic carbon $(\%)$} \\
\hline & 1995 & 2012 & change & 1995 & 2012 & change & 1995 & 2012 & change & 1995 & 2012 & change \\
\hline Kuthanagere -1 & 67.3 & 69.28 & 1.98 & 8.6 & 14.49 & 5.89 & 24.1 & 16.23 & -7.87 & 0.40 & 0.57 & 0.17 \\
\hline Kuthanagere -2 & 70 & 63.71 & -6.29 & 11.6 & 16.45 & 4.85 & 18.3 & 19.84 & 1.54 & 0.34 & 0.50 & 0.16 \\
\hline Kuthanagere $-\mathbf{3}$ & 80.7 & 70.03 & -10.67 & 7.5 & 14.25 & 6.75 & 11.8 & 15.72 & 3.92 & 0.26 & 0.48 & 0.22 \\
\hline Kuthanagere -4 & 65.2 & 69.82 & 4.62 & 5.0 & 12.97 & 7.97 & 29.1 & 17.21 & -11.89 & 0.76 & 0.72 & -0.04 \\
\hline Kuthanagere -5 & 72.1 & 67.15 & -4.95 & 11.9 & 7.43 & -4.47 & 16 & 25.42 & 9.42 & 0.60 & 0.81 & 0.21 \\
\hline Kuthanagere -6 & 68.1 & 67.93 & -0.17 & 11.7 & 11.66 & -0.04 & 20.2 & 20.41 & 0.21 & 0.93 & 0.60 & -0.33 \\
\hline Kuthanagere -7 & 72 & 66.35 & -5.65 & 14.1 & 15.67 & 1.57 & 13.9 & 17.99 & 4.09 & 0.58 & 0.67 & 0.09 \\
\hline Kuthanagere -8 & 75.1 & 60.08 & -15.02 & 13.4 & 8.3 & -5.1 & 11.5 & 31.62 & 20.12 & 0.61 & 0.53 & -0.08 \\
\hline Kuthanagere -9 & 82.1 & 57.21 & -24.89 & 9.8 & 12.31 & 2.51 & 8.1 & 30.48 & 22.38 & 0.25 & 0.71 & 0.46 \\
\hline Kuthanagere -10 & 54.2 & 63.23 & 9.03 & 13.5 & 15.15 & 1.65 & 32.3 & 21.62 & -10.68 & 0.6 & 0.67 & 0.07 \\
\hline Kuthanagere -11 & 84.6 & 79.91 & -4.69 & 9.7 & 6.77 & -2.93 & 5.7 & 13.33 & 7.63 & 0.31 & 0.39 & 0.08 \\
\hline Kuthanagere -12 & 75.8 & 64.78 & -11.02 & 13.6 & 16.6 & 3 & 10.6 & 18.62 & 8.02 & 0.32 & 0.52 & 0.2 \\
\hline Kuthanagere -13 & 64.8 & 64.24 & -0.56 & 9.5 & 10.71 & 1.21 & 25 & 25.05 & 0.05 & 0.42 & 0.55 & 0.13 \\
\hline Average & 71.69 & 66.44 & -5.25 & 10.76 & 12.52 & 1.76 & 17.43 & 21.04 & 3.61 & 0.49 & 0.59 & 0.10 \\
\hline
\end{tabular}


Water harvesting structures (either dug out or nala bunds) and recycling harvested water to cultivate cash crops like chilli, tomatoes, and other vegetables.

\section{Agri horticultural system}

The bird's eye view and a close up view of the Kuthanagere micro watershed before (1992) the watershed programme and after a lapse of 10 and 20 years shown the establishment of mango based agrihorticultural systems in class IV to VII lands. The improvement in land covers is clearly visible in ten years after the plantation. Besides, it generated an employment and income in summer season due to mango fruit bearing in addition to the arable cropping in kharif. On the contrary, only arable cropping viz., finger millet based akkadi system, sole pigeon pea or ground nut in only kharif was found less profitable and unstable due to already established prediction of a drought year once in every five years, on an average. Even in good years of S-W monsoon, the yield of arable crops on these classes IV to VII lands was low compared to class II and III lands. Due to inherent constraints of poor available water holding capacity, shorter length of crop growing periods and poor fertility status of these soils, the present land use mapping showed increased area under agri-horti system to 25.4 per cent and that of arable cropping decreased to 32 per cent in 10 years study, when compared to the past land use of 5.5 and 50.4 per cent, respectively. Further, it is certain in the improvement of standard of living and health due to more availability of balanced diet in terms of nutritive foods and spices from agri-horti systems on these marginal lands, although it's difficult to measure in economic terms.

\section{Silvi-pasture}

It is nothing but growing of forest trees on lands not at all suitable for arable cropping.
Partial view of watershed from north hill side taken before the establishment of Silviculture (May 1992) looked as barren hillock and rock out cropped area. On these scarp slopes of the barren hillock, dominant tree species of fodder, fuel, fruit, fibre, timber and green manure (viz., Aracia auriculiformis, Cassia siamea, Albeia lebbek, Delbergia sissoo, neem, tamarind, jamoon- amla, custard apple, bamboo, agave silk cotton, pongamia and etc.) were planted on contour ' $\mathrm{V}$ ' ditches during the onset of South west monsoon. After 10 and 20 years a lapse of silviculture depicted the remarkable improvement in land cover with forest tress on scarp slopes, gullied lands and also seen are the horticultural trees.

Tree planting on field bunds with silver oak and Casuarina, erect growing canopy spreading type were undertaken as agro forestry systems. These tree species had no shade effect on arable crops. The area under silviculture after 10 years of establishment on severely eroded gullies and on the barren hillocks increased 38.3 per cent of the watershed area

\section{References}

Higgins, G. M., and Kassam, A. K., 1981. FAO- agroecological zone approach to determining of land potential, Pedologie, 31(2): 147-168.

I. A.R.I., 1971. Soil Survey Manual. New Delhi, pp.121.

Shivaramu, H. S., and Niranjana, K. V., 2010. Soil-site suitability evaluation of alfisols for finger millet. Agropedology, 20(2):139-149.

Shivaramu, H. S., Krishnappa, A. M., Shivaprasad, C. R., Ramanagowda, P., Arunkumar, Y. S. and Ranganna, B., 2000. Resource inventory for sustainable development- A case study of Kuthanagere micro watershed, ORPWatershed, Univ. Agric. Sci., Bengaluru. 
Shivaramu, H.S., 2012. Soil suitability assessment for pigeon pea in Alfisols of Karnataka- A modeling approach. Agropedology, 22(2):69-73.

Yadav, S. C., Shivaramu, H. S. and Sehgal, J.,
1995. Effect of soil characters on the yield of rainfed crops in a watershed near Nagpur. Journal of Indian Society of Soil Science, 43(4): 652-656.

\section{How to cite this article:}

Arun Kumar, J.S., H.S. Shivaramu and Anilkumar, S.N. 2017. Impact of Watershed Development on Soil Characteristics in Kuthanagere Micro-Watershed in Ramanagar District of Karnataka, India. Int.J.Curr.Microbiol.App.Sci. 6(10): 2914-2922. doi: https://doi.org/10.20546/ijcmas.2017.610.344 